\title{
Tendencias de investigación en marketing
}

Grupo de Investigación Mercadeo I+2

Julio de 2020

\section{Resumen}

Este número recopila el trabajo de reflexión y síntesis de seis profesores de la Escuela de Marketing y Branding de la Facultad de Sociedad, Cultura y Creatividad de la Institución Universitaria Politécnico Grancolombiano, en torno a diferentes corrientes actuales de investigación en marketing, brindando de esta forma un panorama amplio sobre temáticas tan relevantes como el mercadeo social, el análisis de datos cienciométricos, el consumo creciente de apps móviles, los entornos de comercio modernos y el mercadeo educativo en el contexto de la educación superior. A través de los diferentes documentos se ofrece una perspectiva sobre adelantos recientes a nivel teórico en cada temática, junto con hallazgos y posibles aplicaciones en varias categorías de producto y sectores económicos. Esta edición es el producto de dicho esfuerzo y reúne los seis documentos que hicieron parte de la serie de charlas de actualización en investigación en mercadeo de la Escuela de Marketing y Branding durante la semana del 6 al 10 de julio de 2020.

Palabras clave: Marketing, mercadeo, aplicaciones móviles, mercadeo social, entornos de comercio moderno, mercadeo educativo, bibliometría, internacionalización.

\section{Abstract}

This issue compiles the work of reflection and synthesis of six professors of the School of Marketing and Branding of the Faculty of Society, Culture and Creativity of the Polytechnic Grancolombiano University Institution, around current research trends in different marketing topics, thus providing a broad overview of relevant issues such as social marketing, scientometric data analysis, increasing consumption of mobile apps, modern trading environments and educational marketing in the context of higher education. Through the different documents, a perspective is given on recent advances at a theoretical level in each subject, along with findings and possible applications in various product categories and economic sectors. This issue is the product of that effort and brings together the six papers that were part of the School of Marketing and Branding's Marketing Research Update lecture series during the week of July 6-10, 2020. 
Key words: Marketing, mobile applications, social marketing, modern business environments, educational marketing, bibliometrics, internationalization. 